\title{
ANALISA YURIDIS BIAYA EKSEKUSI PADA LEMBAGA PEMBIAYAAN ${ }^{*}$
}

\author{
Sundaru Guntur Wibowo \\ Politeknik Negeri Madiun, Jl. Serayu No. 84 Madiun \\ e-mail: sundaru.guntur@pnm.ac.id
}

\begin{abstract}
The purchase of consumer goods for the public through financial institutions can answer and be a solution for the community to have these goods, while for financing institutions this is an opportunity to develop their business, both for goods such as cars, motorbikes, furniture and also electronic goods. The community gets the convenience of payments that can be paid in installments according to their ability. The problems and dynamics that arise in this consumer financing agreement are interesting things to study so that people will understand and find solutions. The method used in this study is juridical empirical, using primary data and secondary data and then analyzed using qualitative analysis techniques. The results of the study can answer that the relationship between consumers and financing institutions or companies is the relationship of consumer financing agreements. Consumer financing agreements are always in written form where the agreement clause has been provided by a finance company, or commonly referred to as a standard agreement. With limited purchasing power.
\end{abstract}

Keywords: Consumer Financing, Disobey Of Agreement.

\begin{abstract}
Abstrak
Pembelian barang-barang konsumtif kebutuhan masyarakat melalui lembaga pembiayaan bisa menjawab dan menjadi solusi bagi masyarakat untuk memiliki barang kebutuhan tersebut, sementara bagi lembaga pembiayaan hal tersebut merupakan peluang dalam rangka mengembangkan bisnisnya, baik untuk barang seperti mobil, sepeda motor, mebel dan juga barang elektronik. Masyarakat mendapat kemudahan berupa pembayaran yang bisa diangsur sesuai dengan kemampuan. Permasalahan dan dinamika yang timbul dalam perjanjian pembiayaan konsumen ini merupakan hal yang menarik untuk diteliti sehingga masyarakat akan memahami dan menemukan solusi. Metode yang digunakan dalam penelitian ini adalah yuridis empiris, memakai data primer dan data sekunder dan selanjutnya dianalisa dengan memakai teknik analisa kualitatif. Hasil dari penelitian bisa menjawab bahwa hubungan antara konsumen dan lembaga atau perusahaan pembiayaan adalah hubungan perjanjian pembiayaan konsumen. Perjanjian pembiayaan konsumen selalu berbentuk tertulis dimana klausula perjanjianya sudah disediakan oleh perusahaan pembiayaan, atau biasa disebut dengan perjanjian baku dengan daya beli yang terbatas.
\end{abstract}

Kata Kunci: Pembiayaan Konsumen, Wanprestasi

\footnotetext{
* Naskah diterima: 24 Juli 2018, direvisi: 27 Agustus 2018, disetujui untuk terbit: 24 September 2018
} 


\section{PENDAHULUAN}

Perusahaan pembiayaan merupakan lembaga keuangan non bank yang bentuk kegiatan usahanya antara lain:

1. Sewa guna usaha (leasing)

2. Anjak piutang(Factoring).

3. Kartu kredit (credit car).

4. Pembiayaan konsumen (consumer finance).

5. Modal ventura (venture capital).

6. Perdagangan surat berharga (securities).

Industri otomotif khususnya sepeda motor dimana masyarakat yang menjadi konsumen lebih familiar menyebut dengan kata-kata leasing, padahal hal tersebut salah, yang tepat adalah pembiayaan konsumen, sedangkan leasing sendiri adalah sewa guna usaha.

Jumlah konsumen di setiap cabang perusahaan pembiayaan yang tersebar di berbagai kota di seluruh Indonesia, jumlahnya sangat banyak, dalam istilahnya disebut outstanding. Mencermati besarnya outstanding, perusahaan pembiayaan selalu menggunakan kontrak baku dalam pembuatan perjanjianya, alasanya agar pelayanan lebih cepat dan efisien. Outstanding yang besar dan kontrak baku yang dibuat oleh kreditur tersebut yang pada akhirnya menjadi awal permasalahan, karena yang terjadi masyarakat hanya menanda-tangani klausula kreditnya tanpa memahami terlebih dahulu, sedangkan bagi petugas yang mewakili kreditur juga tidak akan dengan jelas menerangkan apa saja isi detail dari perjanjian tersebut, sehingga kesan yang timbul sekedar tanda-tangan karena setiap hari ada banyak sekali pengajuan aplikasi pembelian melalui lembaga pembiayaan tersebut.

Dalam Pasal 1313 KUHPerdata disebutkan bahwa:

"Perjanjian adalah suatu perbuatan dengan mana satu orang atau lebih mengikatkan dirinya terhadap satu orang atau lebih".

Selanjutnya dalam Pasal 1320 KUHPerdata menyebutkan 4 syarat sahnya perjanjian, yaitu:

1. Adanya sepakat mereka yang mengikatkan dirinya,

2. Kecakapan untuk membuat perikatan,

3. Hal tertentu,

4. Suatu sebab yang halal.

Istilah perjanjian juga dapat diartikan sebagai suatu peristiwa di mana seorang berjanji kepada seorang lain atau di mana dua orang saling berjanji untuk melaksanakan sesuatu. (Komariah 2005:168).

Perjanjian harus memenuhi 3 macam unsur:

1) Essentialia, ialah unsur yang penting dan harus ada dalam suatu perjanjian.

2) Naturalia, ialah unsur yang harusnya ada namun dapat dikesampingkan.

3) Accidentalia, ialah unsur perjanjian yang muncul karena adanya kesepakatan kedua belah pihak.

Pasal 1320 KUHPerdata yang merupakan asas konsesualisme, yaitu di mana perjanjian adalah sah apabila ada kata sepakat. Hal ini berkaitan dengan 
Pasal 1338 ayat (1) KUHPerdata yang juga merupakan asas kebebasan berkontrak, sehingga perjanjian yang dilakukan mengikat para pihak karena menimbulkan hak dan kewajiban bagi para pihak itu sendiri.

Suatu penilaian yang baik terhadap pihak yang akan melaksanakan isi perjanjian merupakan kepatutan. Di mana kepatutan merupakan itikad baik dan harus terpenuhi dalam menerapkan asas kebebasan berkontrak. Hal ini telah diatur di Pasal 1338 ayat (3) KUH Perdata.(Sutan Remy Sjahdeni, 1993: 49)

Asas itikad baik mengandung pengertian, bahwa para pihak memiliki kebebasan dalam menentukan perjanjian sesuai kehendaknya, namun itikad baik yang membatasi perjanjian tersebut. Terkait dengan perjanjian pembiayaan konsumen itikat baik harus dipenuhi oleh para pihak, bagi debitur bisa dengan memberikan data dan keterangan yang sebenarnya, tidak memakai identitas palsu atau yang berbeda dengan aslinya, sedangkan bagi kreditur asas itikat baik misalnya dengan memberikan penjelasan yang jujur isi dari perjanjian pembiayaan dan kemungkinan yang terjadi dalam jangka waktu pembiayaan, misalnya denda, asuransi, jatuh tempo dan juga sampai penyebab dieksekusinya obyek pembiayaan.

Bentuk Pelaksanaan dalam pembuatan perjanjian pembiayaan konsumen, pada umumnya perjanjian itu dibuat dalam bentuk perjanjian baku. Di mana klausula dalam perjanjian baku dibuat oleh salah satu pihak dan pihak lain hanya mengikuti dan menandatangani perjanjian yang telah dibuat tersebut. Apabila pihak tersebut, dalam hal ini konsumen atau debitur yang tidak menandatangani perjanjian baku tersebut maka konsumen tidak akan mendapatkan barang konsumtif yang merupakan objek perjanjian. Pembiayaan konsumen merupakan perjanjian yang didasarkan pada asas kebebasan berkontrak sebagai asas pokok dari hukum perjanjian. Sebagaimana sudah ditentukan di Pasal 1338 Juncto Pasal 1320 KUH Perdata. (Shidarta, 2000: 1).

Pelaksanaan perjanjian umumnya kreditur mempunyai kedudukan yang lebih terlindungi daripada konsumen yang cenderung mempunyai posisi yang lebih lemah, Sehingga bagi pihak calon debitur hanya memiliki dua pilihan, yaitu apabila calon debitur menginginkan jasa atau barang yang ditawarkan kepadanya, maka ia harus sepakat terhadap semua persyaratan dan patuh terhadap perjanjian yang diajukan tanpa melihat apakah konsumen mengetahui dan atau memahami klausula perjanjian tersebut atau tidak, dan apabila mereka tidak menyetujui atau tidak adanya kesepakatan pada syarat-syarat yang diajukan kepadanya, maka mereka harus mengurungkan atau tidak membuat perjanjian dengan pelaku usaha tersebut, jadi pada umumnya pihak pelaku usaha kurang jelas dalam menerangkan isi perjanjiannya.

Perjanjian baku banyak ditemukan penulisan klausula-klausula yang mengatur tentang cara penyelesaian 
sengketa dan klausula eksonerasi, yaitu bunyi perjanjian yang mengandung keadaan yang membatasi atau bahkan menghapus sama sekali suatu tanggung jawab yang seharusnya dibebankan kepada pihak pelaku usaha. Walaupun telah ada perijinan kegiatan sewa beli dan jual beli angsuran dan sewa. Pengaturannya tidak dijelaskan secara terperinci mengenai kedudukan pembeli dan penyewa. (Munir Fuady, 2002: 57).

Berjalanya pembiayaan konsumen menemui berbagai kendala, diantaranya pembayaran terlambat bahkan sampai pada kredit macet. Proses eksekusi jaminan fidusia yang digelapkan terhadap kredit macet diawali dengan pemberian surat peringatan secara bertahap sebanyak 3 (kali) kepada pihak debitur, namun karena masih tidak ada itikad baik dari debitur maka pihak bank akhirnya memutuskan untuk mengeksekusi objek jaminan fidusia tersebut. Permasalahan muncul ketika akan melakukan eksekusi jaminan ternyata jaminan tersebut telah digelapkan oleh pihak debitur, dengan mengalihkannya pada pihak ketiga tanpa ada persetujuan dari pihak bank atau kreditur, oleh karena itulah pihak bank melalui kuasa hukumnya mengajukan permohonan eksekusi kepada Ketua Pengadilan Negeri setempat. (Budi, 2017: 102)

Praktek dalam perjanjian perusahaan pembiayaan memiliki posisi yang kuat daripada posisi pembelinya atau nasabahnya, hal ini di karena adanya resiko yang tidak mau diambil oleh pihak kreditur atau perusahaan pembiayaan apabila terjadinya kendala tidak membayar angsuran yang telah diatur, disepakati, dan dituangkan dalam perjanjian serta ditentukan oleh para pihak, Maka dibuatlah klausula yang memberikan hak kepada kreditur untuk menuntut dan penarikan barang menurut perjanjian yang dilakukannya. Jika terjadi persoalan keterlambatan pembayaran angsuran, pasti yang eksekusi adalah obyek dari perjanjian, baik yang dikerjakan para karyawan perusahaan tersebut atau bekerja sama dengan pihak ketiga. Obyek jaminan yang ditarik tersebut selanjutnya akan dimasukan ke kantor kreditur, debitur bisa kembali meneruskan pembayaran angsurannya tetapi ada beban tambahan selain denda, yaitu yang disebut biaya eksekusi.

Masalah muncul awal dari adanya biaya eksekusi tersebut, karena hal tersebut tidak dengan jelas tertulis pada perjanjian pembiayaan, sehingga debitur merasa keberatan dan akhirnya tidak mampu membayar biaya eksekusi tersebut, sehingga debitur hanya bisa merelakan kendaraannya dilelang oleh perusahaan pembiayaan.

Berdasarkan latar belakang diatas yang menarik untuk diteliti dan dikaji untuk menemukan jawaban mengenai rumusan masalah: Bagaimana Fasilitas pembiayaan diberikan kepada konsumen dan Bagaimana akibat hukum atas biaya eksekusi yang diberlakukan kepada konsumen? 


\section{METODOLOGI PENELITIAN}

Berdasarkan rumusan masalah dan tujuan penelitian maka metode pendekatan yang digunakan adalah metode pendekatan yuridis empiris, Yaitu meneliti data sekunder terlebih dahulu kemudian dilanjutkan dengan mengadakan penelitian data primer di lapangan.

Faktor yuridisnya adalah berbagai peraturan yang berkaitan dengan bidang hukum perjanjian pembiayaan konsumen selanjutnya factor yang dimaksud empirisnya adalah konsumen dan perusahaan pembiayaan konsumen.

\section{PEMBAHASAN}

1. Perusahaan

Pembiayaan

Memberikan Proses Fasilitas Kepada Konsumen

Berdasarkan Surat Edaran Bank Indonesia N0. 15/40/DKMP tanggal 24 september 2013 perihal penerapan manajemen risiko pada bank yang melakukan pemberian kredit atau pembiayaan pemilikan properti, kredit atau pembiayaan konsumsi beragun properti dan kredit atau pembiayaan kendaraan bermotor, intinya mengatur mengenai batasan down payment dengan ketentuan Pengaturan minimum (DP) untuk kredit/pembiayaan kendaraan bermotor yaitu $25 \%$ untuk kendaraan bermotor roda dua, $30 \%$ untuk kendaraan bermotor roda tiga atau lebih untuk keperluan non produktif, dan $20 \%$ untuk kendaraan bermotor roda tiga atau lebih untuk keperluan produktif.
Sedangkan untuk lembaga pembiayaan Otoritas Jasa Keuangan (OJK) menetapkan Surat Edaran OJK NO.47/SEOJK.05/2016 tentang Besaran Uang Muka (Down Payment) Pembiayaan Kendaraan Bermotor Bagi Perusahaan Pembiayaan. Selain itu, bagi sektor pembiayaan syari'ah diterbitkan pula Surat Edaran OJK NO.47/SEOJK.05/2016 tentang Besaran Uang Muka (Down Payment/Urbun) Pembiayaan Kendaraan Bermotor Untuk Pembiayaan Syari'ah. Beleid yang ditetapkan 13 Desember 2016 itu memberikan relaksasi batasan uang muka atau down payment (DP) dengan didasarkan pada tingkat kredit bermasalah ataunon performing financing (NPF) setiap perusahaan pembiayaan atau rasio aset bermasalah pada perusahaan atau unit usaha syari'ah multifinance. Peraturan ini lebih ringan bila dibandingkan dengan peraturan sebelumnya, karena tujuannya untuk mendongkrak bisnis pada industri kendaraan bermotor. Berikut ini, ketentuan DP bagi pembiayaan kendaraan bermotor oleh multifinance :

\begin{tabular}{|c|c|c|c|}
\hline Kondisi Multifinance & Jenis Kendaraan & Konvensional & Syariah \\
\hline \multirow{3}{*}{$\begin{array}{l}\text { Tingkat Kesehatan } \\
\text { Keuangan minimal } \\
\text { sehat. NPF }<1 \%\end{array}$} & Roda 2-3 & $5 \%$ & $5 \%$ \\
\hline & Roda 4 atau lebih untuk tujuan Produktif & $5 \%$ & $5 \%$ \\
\hline & Roda 4 atau lebih untuk tujuan Non-Produktif & $10 \%$ & $5 \%$ \\
\hline \multirow{3}{*}{$\begin{array}{l}\text { Tingkat Kesehatan } \\
\text { Keuangan minimal } \\
\text { sehat. NPF }>1 \% \text { - } \\
<3 \%\end{array}$} & Roda $2-3$ & $10 \%$ & $5 \%$ \\
\hline & Roda 4 atau lebih untuk tujuan Produktif & $10 \%$ & $5 \%$ \\
\hline & Roda 4 atau lebih untuk tujuan Non-Produktif & $15 \%$ & $10 \%$ \\
\hline \multirow{3}{*}{$\begin{array}{c}\text { Tingkat Kesehatan } \\
\text { Keuangan minimal } \\
\text { sehat. NPF }>3 \% \text { - } \\
<5 \%\end{array}$} & Roda $2-3$ & $15 \%$ & $10 \%$ \\
\hline & Roda 4 atau lebih untuk tujuan Produktif & $15 \%$ & $10 \%$ \\
\hline & Roda 4 atau lebih untuk tujuan Non-Produktif & $15 \%$ & $15 \%$ \\
\hline \multirow{3}{*}{$\begin{array}{c}\text { Tingkat Kesehatan } \\
\text { Keuangan minimal } \\
\text { Tidak Sehat. NPF < } \\
5 \%\end{array}$} & Roda $2-3$ & $15 \%$ & 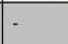 \\
\hline & Roda 4 atau lebih untuk tujuan Produktif & $15 \%$ & - \\
\hline & Roda 4 atau lebih untuk tujuan Non-Produktif & $20 \%$ & - \\
\hline \multirow{3}{*}{$\begin{array}{l}\text { Tingkat Kesehatan } \\
\text { Keuangan minimal } \\
\text { sehat. NPF }>5 \%\end{array}$} & Roda 2 -3 & $20 \%$ & $15 \%$ \\
\hline & Roda 4 atau lebih untuk tujuan Produktif & $20 \%$ & $20 \%$ \\
\hline & Roda 4 atau lebih untuk tujuan Non-Produktif & $20 \%$ & $25 \%$ \\
\hline
\end{tabular}

Perjalanan atau jangka waktu pelaksanaan perjanjian pembiayaan konsumen kerap terjadi keterlambatan 
pembayaran yang dilakukan oleh debitur dengan berbagai macam alasan, bisa karena memang debitur tersebut sedang bermasalah dengan keuangannya, dalam hal ini karena adanya kebutuhan yang tidak terduga dari konsumen, alasan lain adalah keterlambatan yang disebabkan oleh karakter debitur yang kurang baik, hal ini terjadi karena perusahaan pembiayaan atau kreditur tersebut kurang berhati-hati dalam memberikan fasilitas pembiayaan terhadap calon debitur. Hal ini sering kali terjadi karena target yang ditentukan sendiri oleh perusahaan pembiayaan tersebut. (H. Salim HS, 2006: 48)

Perusahaan pembiayaan konsumen umumnya melakukan kegiatan pembiayaan sepeda motor serta kendaraan roda empat (mobil), baik itu mobil pribadi maupun mobil untuk keperluan perdagangan atau niaga. Pola bisnis dan usaha perusahaan pembiayaan dapat dijelaskan sebagai berikut: (Johannes Ibrahim, 2004: 270)

a) Perusahaan pembiayaan menggunakan modal dari induk perusahaan atau Bank memberikan investasi serta pinjaman kredit modal kerja kepada perusahaan pembiayaan

b) Modal usaha tersebut digunakan oleh perusahaan pembiayaan, untuk membiayai konsumen dalam pemberian fasilitas kredit atas barang-barang kebutuhan konsumen.

c) Pihak perusahaan pembiayaan bekerja sama dengan dealer atau untuk masalah pengadaan barang- barang yang hendak di kredit oleh konsumen.

d) Konsumen menerima barang-barang yang hendak di kredit tersebut melalui dealer tempat di mana konsumen mengajukan kredit.

e) Pembayaran pelunasan barangbarang kebutuhan konsumen tersebut kemudian dilakukan oleh perusahaan pembiayaan sebagai pemberi kredit/penanggung kredit konsumen.

f) Konsumen berkewajiban membayar kredit atas barang-barang tersebut kepada perusahaan pembiayaan yang telah mendanai kreditnya. Dalam hal ini pihak dealer sudah tidak terkait lagi dengan urusan pembayaran kredit atas barang-barang kebutuhan konsumen tersebut, hanya saja dealer biasanya membantu menerima pembayaran angsuran yang dilakukan oleh konsumen, kemudian petugas perusahaan pembiayaan akan mengambil angsuran tersebut.

g) Dana yang terkumpul dari angsuran pembayaran kredit yang dilakukan debitur, kemudian dibayarkan lagi kepada bank sebagai pembayaran terhadap hutang perusahaan. Selisih lebih dari pembayaran kredit konsumen terhadap hutangnya merupakan keuntungan bagi perusahaan pembiayaan.

Pada prinsipnya tidak ada perbedaan dalam mekanisme pelaksanaan perjanjian fasilitas pembiayaan konsumen yang dilakukan beberapa perusahaan pembiayaan, di mana dalam penyaluran 
kreditnya harus melalui tahap-tahap yang telah ditentukan yaitu sebagai berikut:

\section{Tahap Permohonan}

Untuk dapat memperoleh fasilitas pembiayaan konsumen berupa barangbarang kebutuhan dan keinginan konsumen, debitur (konsumen) biasanya sudah mempunyai usaha yang baik dan atau telah bekerja, mempunyai pekerjaan layak, serta berpenghasilan yang memadai. Adapun syarat-syarat yang harus dipenuhi oleh debitur (konsumen) untuk dapat mengajukan permohonan fasilitas pembiayaan konsumen, yaitu :

a. KTP calon pemohon kredit

b. KTP penjamin kredit (suami/istri)

c. NPWP (Nomor Pokok Wajib Pajak)

d. Kartu Keluarga/ Surat Nikah bagi konsumen yang telah menikah

e. Slip gaji atau Surat Keterangan yang menunjukkan gaji (jika calon peminjam bekerja formal)

f. Rekening Listrik/ Rekening Telepon/ Rekening Air (PDAM)

g. Surat Keterangan lainnya yang diperlukan.

Permohonan pembiayaan konsumen biasanya dilakukan oleh debitur (konsumen) dengan cara mereka mendatangi toko, suplier atau dealer yang telah melakukan kerja sama dengan perusahaan pembiayaan.

2. Tahap Pengecekan dan Pemeriksaan Lapangan ( survey )

Berdasarkan aplikasi dari pemohon yang telah masuk, Marketing Department akan melakukan survey atau pengecekan lapangan atas kebenaran dari pengisian formulir aplikasi tersebut dengan melakukan analisa dan penilaian terhadap data-data serta informasi yang sudah diterima, yang kemudian dilanjutkan dengan kunjungan ke tempat calon debitur, melakukan pengecekan ke tempat lain atau cek lingkungan, dan melakukan observasi secara umum/khusus lainnya. Tujuan dari pemeriksaan di lapangan adalah untuk memastikan keberadaan debitur dan memastikan akan barang yang dibutuhkan konsumen, untuk mempelajari keberadaan barang kebutuhan konsumen yang dibutuhkan oleh debitur terutama harga kredibilitas supplier/pemasok dan layanan purna jual, untuk mengetahui hitungan pasti berapa besar tingkat kebenaran informasi dari calon debitur dibandingkan dengan laporan yang telah disampaikan.

3. Tahap Pembuatan laporan ringkasan survey

Berdasarkan hasil pengecekan di lapangan, selanjutnya surveyor akan membuat laporan ringkasan survey yang isinya akan menggambarkan tentang:

a. Nama calon debitur dan isteri/suami

b. Alamat dan nomor telepon

c. Tingkat resiko dilihat dari $5 \mathrm{C}$ (character, collateral, capacity, capital, condition economy).

d. kondisi pekerjaan dan analisa penghasilan

e. Analisa data debitur

f. Kondisi Pembiayaan yang diajukan

g. Barang dengan jenis dan tipe apa yang dibutuhkan calon konsumen. 
4. Tahap Pengajuan kredit Kepada Kredit Komite cabang

Setelah data masuk ke surveyor, berikutnya akan dilanjutkan pengajuan lanjutan ke bagian kredit komite yang ada di cabang, pengajuan tersebut formulir dan data yang telah diisi yang memuat:

a) Tujuan pemberian fasilitas pembiayaan konsumen.

b) Struktur fasilitas pembiayaan yang mencakup harga barang, uang muka, bunga, tenor atau jangka waktu, tipe, dan jenis barang.

c) Keterangan tentang debitur yang diperoleh dari informasi lingkungan

d) Analisa Resiko.

e) Saran dan Kesimpulan.

5. Keputusan Kredit Komite

Keputusan Kredit Komite merupakan dasar bagi kreditur untuk mengabulkan permohonan pembiayaan atau tidak. Apabila permohonan debitur di tolak maka harus diberitahukan melalui surat penolakan, sedangkan apabila disetujui maka Marketing Department akan meneruskan tahap berikutnya.

\section{Tahap Pengikatan}

Setelah komite kredit memutuskan penilaiannya, bagian Legal biasanya akan mempersiapkan klausul pengikatan atau perjanjian, sebagai berikut :

a. Perjanjian Pembiayaan Konsumen beserta lampirannya.

b. Jaminan dari pribadi (jika ada)

c. Jaminan Perusahaan (jika ada)

Saat ini pengikatan dalam perjanjian pembiayaan konsumen sifatnya harus notariil, artinya tidak diperbolehkan lagi membuat perjanjian dibawah tangan.

7. Tahap Pemesanan Barang yang diajukan oleh Konsumen

Setelah proses penandatanganan perjanjian dilakukan oleh kedua belah pihak, selanjutnya kreditur akan melakukan hal-hal sebagai berikut :

a) Kreditur melakukan pemesanan barang kepada supplier, pesanan tersebut akan dilakukan dalam bentuk PO (Purchase Order), Bukti Pengiriman, dan Surat Tanda Penerimaan Barang.

b) Khusus untuk objek pembiayaan bekas pakai, akan dilakukan pemeriksaan BPKB oleh bagian administrasi.

c) Penerimaan Pembayaran dari konsumenr kepada kreditur (dapat melalui supplier/dealer), yang meliputi:

i. Pembayaran Pertama, antara lain: uang muka, angsuran pertama, premi asuransi untuk tahun pertama, biaya administrasi, dan pembayaran pertama lainnya (biasanya biaya tersebut dijadikan satu total pembayaran awal)

ii. Pembayaran berikutnya yang meliputi: angsuran berikutnya berupa cheque/bilyet giro mundur, pembayaran premi asuransi untuk tahun berikutnya, dan pembayaran lainnya jika ada. 
8. Tahap Pembayaran Kepada Supplier/dealer

Setelah barang obyek pembiayaan diserahterimakan supplier kepada debitur, selanjutnya supplier akan menagih kepada kreditur dengan melampirkan : kuitansi penuh, kuitansi uang muka, dan atau bukti pelunasan uang muka, purchase order, bukti kirim dan surat tanda terima barang, gesekan nomor rangka dan mesin, surat pernyataan BPKB, kunci duplikat, dan surat jalan (jika ada). Sebelum pembayaran barang dilakukan oleh kreditur kepada supplier, hal-hal yang akan dilakukan oleh kreditur adalah :

a) Melakukan penutupan pertanggungan asuransi ke pihak asuransi yang telah di tunjuk.

b) Melakukan pemeriksaan ulang seluruh dokumentasi perjanjian pembiayaan konsumen oleh bagian administrsi, dengan mempergunakan Form Check List Document.

9. Tahap pembayaran dan Penagihan

Setelah seluruh proses pembayaran kepada supplier/dealer dilakukan, proses selanjutnya adalah pembayaran angsuran dari debitur sesuai dengan jadwal yang telah ditentukan. Adapun sistem pembayaran yang dapat dilakukan yaitu : dengan cara cash dikantor kreditur, cek, giro, transfer, online payment melalui minimarket yang telah bekerja sama dan di tagih langsung. Diberlakukan tambahan biaya administrasi apabila debitur membayar angsuran, yang besarannya bervariasi.
Monitoring pembayaran angsuran dilakukan oleh Collection Department, berdasarkan jatuh tempo pembayaran yang telah ditentukan, dan berdasarkan sistem pembayaran yang diterapkan. Perlu dijelaskan bahwa monitoring oleh kreditur tidak terbatas hanya pada monitoring pembayaran angsuran dari debitur, akan tetapi kreditur juga melakukan monitoring terhadap jaminan, jangka waktu berlakunya jaminan, dan masa berlakunya penutupan asuransi.

\section{Pengambilan Surat Jaminan}

Apabila seluruh kewajiban debitur telah dilunasi (angsuran dan denda jika ada) maka kreditur akan mengembalikan kepada debitur jaminan berupa Buku Pemilik Kendaraan Bermotor (BPKB). Dalam hal pengambilan jaminan ini, yang bisa mengambil adalah konsumen/pemohon kredit itu sendiri, apabila diwakilkan harus ada surat kuasa bermaterai cukup.

Menentukan kualifikasi pemberlakuan biaya eksekusi yang dilakukan oleh perusahaan pembiayaan terhadap debitur yang wanprestasi, kita harus melihat isi dan syarat-syarat perjanjian pembiayaan itu sendiri, karena agar lebih jelas mengenai penyebab dieksekusinya objek perjanjian pembiayaan konsumen, yang akhirnya menimbulkan pemberlakuan biaya administrasi eksekusi.

Timbulnya biaya eksekusi yang diberlakukan oleh kreditur adalah mengacu pada syarat-syarat perjanjian dengan konsumen, yaitu dimana di dalam 
syarat-syarat tersebut kreditur bisa menggunakan pihak lain atau pihak ketiga yang diberikan kuasa untuk menerima kapanpun dan dimanapun dan ditempat siapapun jaminan tersebut berada, kemudian apabila dari proses tersebut terhitung ada biaya yang timbul dan perhitungan biaya tersebut akan ditentukan oleh kreditur. Jika mencermati kenyataan apa yang terjadi dilapangan, bahwa yang dilakukan kreditur adalah memberi surat kuasa untuk melakukan eksekusi atas obyek jaminan, sehingga bukan serah terima seperti bunyi dalam syarat-syarat perjanjian.

Proses eksekusi itulah yang kemudian akan menimbulkan biaya eksekusi, biaya tersebut akan dihitung dan dibebankan kepada debitur yang obyek jaminanya telah dieksekusi. Biaya eksekusi tersebut merupakan hukuman tambahan kepada debitur, karena debitur telah wanprestasi.

Kualifikasi obyek perjanjian yang dieksekusi dan diterima oleh perusahaan pembiayaan yang kemudian akan menyebabkan diberlakukanya biaya eksekusi yang dibebankan oleh kreditur kepada debitur, sebagai berikut:

1. Konsumen/nasabah sendiri atau wakilnya yang menyerahkan objek perjanjian/kendaraanya kepada kreditur karena merasa berat dan tidak mampu untuk membayar angsuran sampai lunas.

2. Eksekusi yang dilakukan oleh petugas collection departement karena konsumen menunggak angsuran/wanprestasi.
3. Eksekusi yang dilakukan oleh pihak ketiga atau biasa disebut (eksternal/debt collector) atas dasar surat kuasa dari kreditur. Eksekusi bisa dilakukan kapanpun dan dimanapun.

Pada tahap ini pemberlakuan biaya eksekusi akan sangat besar, karena pihak penerima kuasa akan menerima insentif yang besar atas keberhasilannya melakukan eksekusi, sedangkan bagi kreditur keuntungannya adalah objek perjanjian bisa diamankan dan akan dilakukan penjualan/pelelangan.

Berakhirnya perjanjian pembiayaan konsumen ini sesuai dengan kesepakatan para pihak sehingga sudah barang tentu di sini terdapat kemungkinan cara untuk mengakhirinya. Adapun kemungkinankemungkinan yang dapat dijadikan cara untuk mengakhiri suatu perjanjian tersebut: 1. Apabila angsuran telah dibayar lunas; 2. Apabila salah satu pihak meninggal dunia dan tidak ada ahli warisnya yang meneruskan, atau mungkin ada ahli warisnya yang namun tidak mau meneruskan; 3. Apabila terjadi perampasan barang yang menjadi obyek perjanjian pembiayaan konsumen 4 . Apabila setelah adanya putusan dari pengadilan yang bersifat tetap. (Khair, 2017: 40).

\section{Akibat Hukum Biaya Eksekusi dalam Perjanjian Pembiayaan Konsumen}

Menarik untuk dikaji mengenai penerapan eksekusi ini, karena hal tersebut tidak secara jelas disebutkan 
dalam isi dan syarat-syarat perjanjian ataupun dalam penjelasan umum pada saat karyawan dari perusahaan pembiayaan

(surveyor/marketing) melakukan proses awal perjanjian. Selama ini yang banyak terjadi kreditur bisa menentukan sendiri besaran nominal biaya eksekusi tersebut yang tentunya memberatkan dan merugikan debitur, karena biaya tersebut harus dibayar sekaligus selain jumlah angsuran yang tertunggak dan denda. Akibatnya adalah debitur seringkali pasrah dan tidak mampu lagi membayar atau menebus kembali objek perjanjian pembiayaan tersebut, selanjutnya objek perjanjian itu akan dilelang oleh kreditur.

Tentunya hal ini menimbulkan akibat hukum yang sebenarnya juga akan merugikan perusahaan pembiayaan itu sendiri terutama mengenai nama baik perusahaan itu yang kemudian akan berakibat menurunnya atau bahkan hilangnya kepercayaan calon debitur lain terhadap perusahaan pembiayaan itu.

Hukum harus mengandung 3 (tiga) nilai identitas, yaitu (Peter Mahmud Marzuki, 2008: 160).

a. Asas kepastian hukum (rechtmatigheid). Asas ini meninjau dari sudut yuridis.

b. Asas keadilan hukum (gerectigheit). Asas ini meninjau dari sudut filosofis, dimana keadilan adalah kesamaan hak untuk semua orang di depan pengadilan.

c. Asas kemanfaatan hukum (zwechmatigheid atau doelmatigheid atau utility).
Mencermati tujuan dari Otoritas Jasa Keuangan (OJK) dibentuk adalah, agar keseluruhan kegiatan di dalam sektor jasa keuangan:

1. Terselenggara secara teratur, adil, transparan, dan akuntabel,

2. Mampu mewujudkan sistem keuangan yang tumbuh secara berkelanjutan dan stabil, dan

3. Mampu dan melindungi konsumen serta masyarakat

Sedangkan fungsi Otoritas Jasa Keuangan yaitu mengatur sektor jasa keuangan agar teratur secara komprehensif.

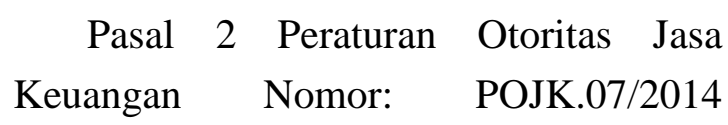
Tentang Perlindungan Konsumen Sektor Jasa Keuangan, perlindungan konsumen menerapkan prisip:
a. Transparansi
b. Perlakuan yang adil
c. Keandalan
d. Kerahasiaan dan keamanan data/informasi konsumen, dan
e. Penanganan pengaduan serta penyelesaian sengketa konsumen secara sederhana, cepat dan biaya terjangkau.

Apabila kita melihat pasal diatas, maka pemberlakuan biaya eksekusi yang tidak tertulis dalam perjanjian secara jelas, bisa dikategorikan melanggar dari ketentuan pasal tersebut, karena tidak transparan apalagi pemberlakuannya yang memungkinkan tidak sama antara satu konsumen/debitur dengan yang lain.

Transparansi menurut pasal ini adalah memberikan layanan yang jelas, terperinci, lengkap, penjelasannya bisa dimengerti dengan mudah, Sedangkan 
mengenai keandalan, di sini juga bisa dipertanyakan, karena dalam melakukan eksekusi, petugas bagian eksekutor seringkali menggunakan jasa pihak ketiga yang tahunya hanya melakukan eksekusi atas objek jaminan, sehingga cara eksekusi yang dilakukan lebih mengarah kepada aksi premanisme. Selanjutnya masalah kerahasiaan dan keamanan data dan/informasi konsumen, hal ini juga tidak bisa dilaksanakan dengan baik, karena pihak ketiga yang diberi kuasa untuk melakukan eksekusi tersebut juga mengajak pihak-pihak lain yang sebenarnya tidak punya kuasa untuk melakukan eksekusi, pihak ketiga tersebut bekerja bersama-sama, bisa sampai beberapa orang, hal ini membuat tidak adanya kerahasiaan data konsumen, karena banyaknya pihak yang turut membantu pihak ketiga tersebut juga dari berbagai pihak, data konsumen akan dengan mudah tersebar.

Pasal 4 POJK Nomor: 1/POJK.07/2013:

(1) Pelaku Usaha Jasa Keuangan wajib menyediakan dan/atau menyampaikan informasi mengenai produk dan/atau layanan yang akurat, jujur, jelas, dan tidak menyesatkan.

(2) Informasi sebagaimana dimaksud pada ayat (1) dituangkan dalam dokumen atau sarana lain yang dapat digunakan sebagai alat bukti.

(3) Informasi sebagaimana dimaksud pada ayat (1) wajib:

a. Disampaikan pada saat memberikan penjelasan kepada Konsumen mengenai hak dan kewajibannya; b. disampaikan pada saat membuat perjanjian

b. Dengan Konsumen; dan c. Dimuat pada saat disampaikan melalui berbagai media antara lain melalui iklan di media cetak atau elektronik.

Mengacu pasal tersebut biaya administrasi eksekusi dalam perjanjian pembiayaan konsumen yang tidak tertulis dengan jelas akan menyesatkan konsumen, karena konsumen/debitur tidak tahu sebelumnya kalau ternyata kreditur bisa menerapkan biaya tersebut. Informasi tersebut tidak pernah dijelaskan secara rinci dan jelas kepada konsumen, seringkali konsumen hanya tahu jika objek pembiayaan tersebut akan ditarik jika konsumen tersebut wanprestasi kemudian konsumen diberikan waktu untuk mengurus kelanjutan kreditnya di perusahaan pembiayaan tersebut. Sehingga hal ini bisa disebut informasi yang diperoleh konsumen/debitur tersebut tidak jelas dan tidak jujur.

Lebih jauh Pasal 10 berbunyi

(1) Pelaku Usaha Jasa Keuangan wajib memberikan informasi mengenai biaya yang harus ditanggung Konsumen untuk setiap produk dan/atau layanan yang disediakan oleh Pelaku Usaha Jasa Keuangan.

(2) Pelaku Usaha Jasa Keuangan dilarang memberikan fasilitas secara otomatis yang mengakibatkan tambahan biaya tanpa persetujuan tertulis dari Konsumen.

Pasal ini jelas menentukan bahwa biaya eksekusi harus dijelaskan dan dituliskan secara lengkap, berapa jumlahnya dan macam-macam biaya apa saja yang nantinya bisa dibebankan kepada konsumen/debitur. 
Sehubungan dengan Peraturan

Otoritas Jasa Keuangan tersebut, maka penerapan biaya yang tidak tertulis dengan jelas berpotensi menimbulkan sengketa antara kreditur dan debitur.

Berdasarkan Peraturan Otoritas Jasa Keuangan Nomor: 1/POJK.07/2014 Pasal 2 menyebutkan:

1) Pengaduan wajib diselesaikan terlebih dahulu oleh lembaga jasa keuangan

2) Dalam hal tidak terjadi kesepakatan penyelesaian pengaduan sebagaimana dimaksud pada ayat (1), konsumen dan lembaga jasa keuangan dapat melakukan penyelesaian sengketa diluar pengadilan atau melali pengadilan

3) Penyelesaian diluar sengketa diluar pengadilan sebagaimana dimaksud pada ayat (2) dilakukan melalui lembaga alternatif penyelesaian sengketa

4) Lembaga alternatif penyelesaian sengketa sebagaimana dimaksud pada ayat (3) dimuat dalam daftar lembaga alternatif penyelesaian sengketa yang ditetapkan oleh OJK

5) Penyelesaian sengketa melalui lembaga alternatif penyelesaian sengketa sebagaimana dimaksud pada ayat (4) bersifat rahasia.

Permasalahan muncul bagi pelaku usaha/perusahaan pembiayaan yang memberlakukan biaya eksekusi yang tidak tertulis dalam perjanjian pembiayaan adalah sanksi yang cukup berat, hal tersebut bisa terjadi dan dialami apabila langkah penyelesaian diluar pengadilan tidak tercapai.

Ancaman sanksi yang bisa menjerat pelaku usaha disebutkan dalam pasal 53
POJK Nomor: 1/POJK.07/2013 sebagai berikut :

"Pelaku usaha jasa keuangan dan/atau pihak yang melanggar ketentuan dalam peraturan otoritas jasa keuangan ini dikenakan sanksi administratif, antara lain berupa:

a) Peringatan tertulis

b) Denda yaitu kewajiban untuk membayar sejumlah uang tertentu

c) Pembatasan kegiatan usaha

d) Pembekuan kegiatan usaha, dan

e) Pencabutan izin kegiatan usaha."

Sanksi dalam pasal 53 diatas tentu saja menjadi permasalahan serius dan merupakan akibat hukum yang harus ditanggung oleh pelaku usaha/perusahaan pembiayaan, tidak sebanding dengan nilai biaya eksekusi yang diberlakukan terhadap konsumen/debitur yang dianggap wanprestasi.

\section{SIMPULAN}

1. Pemberlakuan biaya eksekusi oleh Perusahaan pembiayaan/kreditur terhadap obyek pembiayaan, terjadi jika debitur wanprestasi, eksekusi bisa dilakukan oleh karyawan perusahaan pembiayaan ataupun pihak ketiga berdasarkan surat kuasa, dan terhadap semua obyek pembiayaan yang telah dieksekusi tersebut akan dikenakan atau dibebankan biaya tambahan yang disebut biaya eksekusi.

2. Biaya eksekusi merupakan permasalahan berikutnya yang terjadi akibat dari eksekusi tersebut, diberlakukannya biaya eksekusi kepada debitur/konsumen yang hendak meneruskan kembali angsurannya, dimana biaya tersebut 
tidak tertulis secara jelas di dalam perjanjian dan syarat-syarat perjanjian pembiayaan. implikasi hukum dan melanggar Peraturan Otoritas Jasa Keuangan N0.7/POJK/2014 Tentang Perlindungan Konsumen Sektor Jasa Keuangan.

\section{REKOMENDASI}

1. Perusahaan harus memperhatikan besaran uang muka dari konsumen, artinya apakah uang muka itu murni dari konsumen atau dari subsidi yang diberikan oleh dealer, hal tersebut akan mempengaruhi kelancaran dalam perjalanan perjanjian kreditnya.

2. Perusahaan pembiayaan selaku kreditur harus dengan jelas menuliskan seluruh isi dan akibat yang mungkin timbul dalam proses perjanjian pembiayaan konsumen, harus jelas kapan dan berapa jumlah biaya administrasi itu diberlakukan, selain itu pihak kreditur pada saat awal pembuatan perjanjian kredit juga harus menerangkan hal tersebut agar semua debitur/konsumenya bisa mengerti sehingga selama pelaksanaan perjanjian berlangsung meminimalisir sengketa yang mungkin terjadi. Selain itu pihak debitur/Konsumen harus menyadari kewajibannya untuk melakukan pembayaran dengan tepat waktu serta tidak melakukan tindakan-tindakan yang dilarang oleh pihak perusahaan pembiayaan sehingga dalam pelaksanaan perjanjian pembiayaan konsumen dapat berjalan dengan lancar serta tidak merugikan masingmasing pihak.

3. Hendaknya dipertimbangkan penerapan biaya eksekusi tersebut tidak terhadap semua objek perjanjian yang telah dieksekusi, sebaiknya dilihat dulu kenapa terjadi wanprestasi yang mengakibatkan objek perjanjian tersebut dieksekusi, hal ini menurut penulis penting untuk menjaga nama baik perusahaan pembiayaan.

4. Tindakan penting lain adalah, dalam melaksanakan eksekusi sebaiknya didampingi oleh pihak kepolisian agar berjalan baik sehingga meminimalisir timbulnya sengketa.

\section{DAFTAR PUSTAKA}

\section{Buku-Buku}

Sutan Remy Sjahdeni, 1993, Kebebasan Berkontrak Dan Perlindungan Yang Seimbang Bagi Para Pihak Dalam Perjanjian Kredit Bank Di Indonesia, Institut Bankir Indonesia, Jakarta.

H. Salim HS, 2006, Perkembangan Hukum Kontrak Diluar KUH Perdata, PT. Raja Grafindo Persada, Jakarta.

Johannes Ibrahim, 2004, Mengupas Tuntas Kredit Komersial dan Konsumtif Dalam Perjanjian Kredit Bank (Perspektif Hukum dan Ekonomi), Mandar Maju, Bandung.

Sidharta, 2000, Hukum Perlindungan Konsumen Indonesia, PT, Grasindo, Jakarta. 
Sundaru Guntur Wibowo: Analisa Yuridis Biaya Eksekusi Pada Lembaga Pembiayaan

Peter Mahmud Marzuki, 2008, Pengantar Ilmu Hukum, Kencana, Jakarta.

Komariah, 2005, Hukum Perdata, UMM Press, Malang.

Munir Fuady, 2002, Jaminan Fidusia cetakan kedua revisi, PT. Citra Aditya Bakti, Bandung

Khair Umul, 2017, Analisis Yuridis Perjanjian Pembiayaan Konsumen Dan Akibat Hukum Jika Terjadi Wanprestasi Dalam Perjanjian Pembiayaan Konsumen Di Indonesia. Jurnal Cendekia Hukum: Vol. 3, No 1.hlm 32-40

Budi Setia, 2017 Permohonan Eksekusi Kepada Pengadilan Negeri Berkaitan Dengan Perjanjian
Fidusia Terhadap Jaminan Yang Digelapkan. Cendekia Hukum: Vol 3, No. 1 hlm 99-107.

\section{Peraturan Perundang-undangan}

Keputusan Presiden Republik Indonesia Nomor 61 Tahun 1988 Tentang Lembaga Pembiayaan.

Keputusan Menteri Keuangan Republik Indonesia Nomor 172/KMK.06/2002 Tentang Perusahaan Pembiayaan.

Peraturan Otoritas Jasa Keuangan, POJK No:1/POJK.07/2013

Kitab Undang-Undang Hukum Perdata, Buku III Tentang Hukum Perikatan Dengan Penjelasannya, 1996 Alumni, Bandung. 